Volume 1, Nomor 1, Juli 2018

P-ISSN: 2622-2280 | E-ISSN: 2622-4658

https://ejurnal.iiq.ac.id/index.php/alfanar

\title{
IDENTITAS ÂZAR DALAM LITERATUR TAFSIR NUSANTARA
}

\section{Egi Sukma Baihaki ${ }^{1}$}

Sekolah Tinggi Filsafat Islam (STFI) Sadra Jakarta

Email:egisukma_baihaki@yahoo.com

\begin{abstract}
Azar is one character names enshrined in the Qur'an, which appears in the story of Ibrâhim's preaching dialogue. The figure of Âzar into a debate among historians as well as mufassir. The difference of views regarding the identity of Azar, closely related to the sources of the Torah, which was used as a comparison to explain the figure of Âzar mentioned in the Qur'an. The identity of Âzar in the end, a debate in the realm of theol ogy, as it pertains to the sanctity of nasab to the prophets. Differences of interpretation regarding the identity of Âzar keeps going, in every time and every interpretation of written. This also happens in the interpretation of the archipelago. With the method of comparative thematic and theological approach, it can be concluded that, there are three views on the identity of Âzar in the literature the interpretation of the archipelago. First, Âzar was Ibrâhîm's father which included these groups is Hasbi, Hamka was the Tafsir Kemenag RI. Second, Âzar was Ibrâhim's uncle, which useudes this group is al-Nawawi and Quraish Shihab. A second view of the exegetes this Archipelago has theological ramifications. For those who consider Azar was Ibrâhim's biological father, then they are not disputed there was a pagan Prophet who parents, but for those who think that their father is not Azar theologically they hold on the sanctity of nasab the Prophet spared from the pagan ancestors.
\end{abstract}

Keywords: Nasab, Nusantara, Theology, Nubuwwah.

\begin{abstract}
Abstrak
Azar merupakan salah satu nama tokoh yang diabadikan dalam Al-Qur'an, yang muncul dalam kisah dialog dakwah Ibrâhim. Sosok Âzar menjadi perdebatan dikalangan sejarawan maupun mufasir. Perbedaan pandangan mengenai identitas $\hat{A} z a r$, berkaitan erat dengan sumber Taurat yang dijadikan sebagai pembanding untuk menjelaskan sosok Âzar yang disebutkan Al-Qur'an. Identitas Âzar pada akhirnya, menjadi perdebatan yang masuk dalam ranah teologi, karena berkaitan dengan kesucian nasab para nabi. Perbedaan penafsiran mengenai identitas Azar terus terjadi, dalam setiap masa dan setiap tafsir ditulis. Hal ini juga yang terjadi dalam tafsir Nusantara. Dengan metode tematik tokoh-komparatif dan pendekatan teologis dapat disimpulkan bahwa, ada tiga pandangan mengenai identitas Azar dalam literatur tafsir Nusantara. Pertama, Azar adalah bapak kandung Ibrâhîm, yang termasuk kelompok ini adalah Hasbi, Hamka, dan Kementerian Agama RI. Kedua, Âzar adalah paman Ibrâhîm, yang termasuk kelompok ini adalah Nawawi.
\end{abstract}

1 Mahasiswa STFI Sadra Jakarta pada Program Sarjana, Fakultas Ushuludin, Prodi Ilmu AlQur'an dan Tafsir. 
Ketiga, cenderung mengakomodir dan menengahi kedua pandangan sebelumnya, yang termasuk kelompok ini adalah Quraish Shihab. Ketiga pandangan para mufasir Nusantara ini, memiliki konsekuensi teologis. Bagi yang menganggap Âzar adalah bapak kandung Ibrâhîm, maka mereka tidak mempermasalahkan ada orang tua nabi yang kafir, tapi bagi mereka yang menganggap bahwa Azar bukan ayah Ibrâhîm, secara teologis mereka berpegang pada kesucian nasab para nabi yang terhindar dari leluhur yang kafir.

Kata kunci: Nasab, Nusantara, Teologi, Nubuwwah.

\section{PENDAHULUAN}

Dara Nabi dan Rasul selain mengemban misi untuk menyampaikan risalah kenabian 1 kepada umatnya, juga memiliki tanggung jawab untuk memulai gerakan tersebut dari lingkup yang terdekat yaitu keluarga. Al-Qur'an sendiri mengisahkan cerita mengenai perjuangan para pembawa risalah dalam menyampaikan dakwahnya kepada keluarga mereka. Diantaranya adalah kisah mengenai dakwah Ibrâhîm. Sosok Ibrâhîm memiliki kedudukan penting dalam sejarah kenabian dan peradaban agama yang mendapatkan gelar sebagai "Khalîlullah" dan "Ab al-Anbiyâ".

Al-Qur'an menceritakan bagaimana perjuangan seorang Ibrâhîm mengajak salah satu dari keluarganya agar mengesakan Allah. Sosok anggota keluarga Ibrâhîm ini dalam AlQur'an dilabeli dengan kata "abîhi" dan dari sekian banyak ayat yang mengisahkan dialog Ibrâhîm dengan sosok keluarganya ini, hanya ada satu ayat yang menyebutkan secara jelas siapa yang dimaksud Al-Qur’an sebagai lawan bicara Ibrâhîm yang dilabeli abîhi itu. AlQur'an menyebutkan sosok itu bernama Âzar. ${ }^{3}$

Sahabuddin menyebutkan bahwa kata Âzar adalah sebutan bagi orang Ibrâhîm, yang terdapat di dalam Al-Qur'an QS. al-An'âm [6]: 74. Dialog Ibrâhîm dan sosok Âzar juga dibahas pada QS. at-Taubah [9]: 114, QS. Maryam [19]: 42, QS. al-Anbiyâ’ [21]: 52, QS. asy-Syu'arâ' [26]: 70, QS. ash-Shaffât [37]: 85, QS. az-Zukhrûf [43]: 26, dan QS. al-Mumtahanah [60]: 4. Meski pada ayat-ayat ini tidak disebutkan namanya, Al-Qur'an hanya mengisyaratkannya dengan kata abîhi (ayahnya). Pada ayat lain juga terdapat ungkapan Ibrâhîm kepada ayahnya dengan menggunakan kata yâ abati yang terdapat pada QS. Maryam [19]: 42-45.4

Persoalan perbedaan penafsiran yang muncul di kalangan mufasir terkait dengan identitas Âzar juga ikut dipengaruhi adanya riwayat mengenai keterjagaan atau kesucian nasab para nabi. ${ }^{5}$ Dalil riwayat tersebut digunakan oleh sebagian mufasir untuk menguatkan penafsiran mereka bahwa Âzar bukanlah ayah Ibrâhîm. Misalnya ath-Thûsi saat menafsirkan QS. al-An'âm [6]: 74, ia mengutip hadis yang menyatakan bahwa Allah memindahkan Nabi Muhammad dari sulbi yang suci ke rahim yang suci. Karena itu, athThûsi beranggapan bahwa Âzar bukan ayah Ibrâhîm yang beriman, tetapi ia adalah kakek

\footnotetext{
2 QS. az-Zukhrûf [43]: 26, dan QS. al-Anbiyâ' [21]: 52.

QS. al-An'âm [6]: 74.

4 Sahabuddin (et.al), Ensiklopedi Al-Qur'an: Kajian Kosa Kata, (Tangerang: Lentera Hati, 2007),
} Vol. 1, h. 114-115.

Misalnya, (HR. Abû Nu'aim, Dalâil an-Nubuwwah), (HR. Bukhâri), (HR. Muslim dan Tirmidzi), (HR. Ibn Asâkir), (HR. Ibn Mardawaih). Abi Na'îm Al-Ashbahâni, Dalâil an-Nubuwwah (Bairut: Dâr an-Nafâis, 1986) Jil. 1, h. 57-59. 
dari ibu atau paman Ibrâhîm. Jika ayah Ibrâhîm kafir menurutnya maka tidak mungkin riwayat itu menyebut nenek moyang Nabi Muhammad sebagai orang suci. ${ }^{6}$

Identitas dari sosok Âzar ini selain apakah ia merupakan ayah atau paman Ibrâhîm, juga ada yang memperdebatkan terkait namanya. Kedua perdebatan ini saling berkaitan erat satu sama lain. Ada yang beranggapan bahwa nama Âzar adalah nama asli ayah Ibrâhîm, tetapi ada juga yang menganggap bahwa Âzar adalah nama panggilan bagi ayah Ibrâhîm, sedangkan nama aslinya adalah Tarah. Pandangan lain menyebutkan bahwa Âzar bukanlah nama ayah Ibrâhîm, ia adalah paman Ibrâhîm. Sementara ayah Ibrâhîm sendiri bernama Tarah. Nama Tarah sendiri sebagian berbeda pandangan mengenai huruf akhir nama tersebut ada yang menyatakan Tarah dan ada yang menyatakan Tarukh. ${ }^{7}$

Perdebatan ini telah masuk dalam dimensi teologis karena berkaitan dengan term kenabian. Apalagi dengan adanya beragam pandangan penafsiran dari para mufassir. Penafsiran Al-Qur'an sendiri tidak bisa lepas dari latar belakang seorang mufasir termasuk persoalan teologi yang dianutnya. Karena itulah, persoalan mengenai identitas Âzar juga menjadi perdebatan teologis antar para mufasir. ${ }^{8}$

Masuknya Islam ke Nusantara tidak hanya sekedar masuknya suatu agama ke suatu wilayah, tetapi masuknya Islam ke Nusantara juga membawa masuk sebuah peradaban agama dan perangkatnya. Pengetahuan ke-Islaman, kajian Al-Qur'an, dan isu-isu teologi menjadi bagian yang tidak terpisahkan ikut dan berkembang bersamaan dengan masuknya Islam ke Nusantara yang menjadi bagian dari proses transmisi pengetahuan.?

Dengan menggunakan metode tematik tokoh komparatif dan pendekatan teologis, penelitian ini ingin melihat apakah para mufasir Nusantara terlibat dalam diskursus mengenai identitas Âzar dalam penafsiran yang mereka lakukan, serta bagaimana konsekuensi teologis atas pandangan mereka mengenai identitas Âzar itu?

\section{IDENTITAS ÂZAR DALAM PERADABAN KLASIK}

Sebagaimana disebutkan sebelumnya, persoalan mengenai identitas Âzar mewarnai sejarah, baik diantara kalangan para sejarawan maupun mufasir. Perbedaan pendapat ini terjadi karena kebanyakan sejarawan dan juga para mufasir membandingkan antara nama lawan bicara Ibrâhîm dalam kisah dialog dengan anggota keluarganya dan antara nama yang disebutkan dalam Al-Qur'an dengan nama yang disebutkan dalam kitab terdahulu.

6 Muhammad bin al-H asan ath-Thûsî, at-Tibyân fì Tafsîr Al-Qur'ân, (Beirut: Dâr Ihyâ at-Turâts al-'Arabiyyah, t.th.), Jil. 4, h. 175-176.

Beragam pandangan para mufassir mengenai sosok Âzar ini dapat dilihat pada beberapa kitab tafsir seperti, Ibn Katsîr ad-Dimashqî, Tafsîr Al-Qur'an al-'Azhîm, (Beirut: Dâr al-Fikr, 2011 M/1433 H) Jil. 2, 674. Lihat juga Abî al-Qâsim Mahmûd bin 'Umar az-Zamakhsyarî, al-Kasysyâf 'an Haqâiq Ghawâmidh at-Tanzîl wa 'Uyûn al-'Aqâwîl fî̀ Wujûh at-Ta'wîl, Tahqiq Ahmad Abd al-Maujûd dan 'Alî Muhammad Muawwad, (Riyad: Maktabah Abîkan, 1418 H/1998 M) Jil. 2, h. 365-366. Ar-Râzi dalam tafsirnya mengulas sangat panjang mengenai persoalan identitas Azar. Lihat, Muhammad bin 'Umar alFakhruddîn ar-Râzî, Mafâtin al al-Ghaib, (Beirut: Dâr Ihyâ' at-Turâts al-'Arabi, 1420 H) Jil. 13, h. 29-34.

8 Tafsir merupakan karya manusia yang selalu diwarnai pikiran, mazhab, dan atau disiplin ilmu yang ditekuni oleh sang mufasir. Kadar. M. Yusuf, Studi Al-Qur'an, (Jakarta: Amzah, 2012), h. 161.

9 Transmisi pengetahuan Timur Tengah berkembang sejak masuknya Islam ke Nusantara. Karena masuknya Islam ke Nusantara tidak hanya dipahami sebagai masuknya agama semata, tetapi juga masuk di dalamnya aturan-aturan dan pengetahuan yang berkaitan dengan agama itu sendiri. Abdul Munip, Transmisi Pengetahuan Timur Tengah ke Indonesia: Studi Tentang Penerjemahan Buku Berbahasa Arab di Indonesia 1950-2004, (Jakarta: Puslitbang Lektur Keagamaan Balitbang Diklat Kemenag RI, 2010), h. 37. 
'Abdul Hakîm al-Arwâsyi menganggap bahwa Âzar bukanlah ayah kandung Ibrâhîm, tetapi ayah kandung Ibrâhîm adalah Tarûkh berdasarkan informasi dari para Hawari dan Rahib yang bersumber pada Taurat dan Injil yang terlindungi dari perubahan. ${ }^{10}$ Kamal asSayyid juga menganggap bahwa Âzar bukanlah ayah dari Nabi Ibrâhîm tapi kakek Nabi Ibrâhîm dari jalur ibunya karena itu Nabi Ibrâhîm memanggilnya ayah. ${ }^{11}$

Sedangkan di lain pihak, ada juga yang tetap menyakini bahwa Ibrâhîm adalah anak dari Âzar, misalnya saja asy-Syâfi' $1,{ }^{12}$ Muhammad Bakr Ismâ' $i l,{ }^{13}$ al-Basyûni, ${ }^{14}$ Adib Bisri, dan Abdul Mujîb, ${ }^{15}$ Ali ash-Shâbuni, ${ }^{16}$ al-Maghlouth, ${ }^{17}$ al- Hamid al- $\underline{\text { Huusaini, }}{ }^{18}$, Iqbal Harahap, ${ }^{19}$ M. Ahmad Jadul Mawla, dan M. Abu al-Fadhl. ${ }^{20}$ Bahkan Afîf 'Abdul Fatâh Thabbarah menyatakan bahwa orang tua Ibrâhîm merupakan bagian dari orang pertama yang menyembah berhala. ${ }^{21}$

Sementara itu ath-Thabarî menyebutkan beberapa perbedaan para ulama mengenai Âzar. Pertama, sebagian ulama berpendapat bahwa Âzar adalah nama bapaknya. Mereka menyebutkan tiga riwayat dari (1) Muhammad bin al-Husain, (2) Ibnu Humaid, dan (3) Ibnu al-Barqî. ${ }^{22}$ Kedua, berpendapat bahwa Âzar bukanlah ayah Ibrâhîm dengan menyebutkan empat riwayat dari (1) Muhammad bin Humaid dan Sufyân bin Wâki', (2) Al-Hârrits, (3) Ibnu Wâki', dan (4) Muhammad bin al-Husain. ${ }^{23}$ Ketiga, berpendapat bahwa Âzar merupakan panggilan hinaan atau celaan yang bermakna bengkok atau menyimpang yaitu menyimpang dari kebenaran. ${ }^{24}$

10 'Abdul Hakîm bin Musthafâ al-Arwâsyi, Al-Muntakhabât Min Rasâil as-Sayyid 'Abd al-Hakîm al-Arwâsyi 'alaihi ar-Rahmat wa al-Ridwân, (Istanbul: Maktabah al-Haqîqah, 2014), h. 221-225.

11 Kamal as-Sayyid, Kisah-kisah Terbaik Al-Qur'an, terj. Selma Anis, (Jakarta: Pustaka Zahra, 2004), h. 61.

12 Muhammad Idrîs al-Syâfi'i, Tafsîr al-Imâm asy-Syâfi'i, tahqiq Majdi bin Manshûr bin Sayyid al-Syûrâ (Beirut: Dâr al-Kutub al-'Ilmiyyah, 2009), h. 119.

13 Muhammad Bakr Ismầîl, Qashâs Al-Qur'an min Âdam 'Alaihi as-Salâm Ilâ Ashbâab al-Fîl (t.tp: Dâr al-Manâr, 1418 H/1997 M), h. 57. Lihat juga, Jalâl ad-Dîn as-Suyûthi, Al-Itqân fî Ulûm Al-Qur'ân, terj. Farikh Marzuqi Ammar dan Imam Fauzi Ja’iz, (Surabaya, PT Bina Ilmu Surabaya, t.th.), Jil. 4, h. 91

14 Hamîd Aḥmad at-Thâhir al-Bashûni, Shahîh Qashâsh Al-Qur'ân, (Kairo: Dâr al-Hadîs, 1426 H/2005 M), 133.

15 M. Adib Bisri dan Abdul Mujieb AS, Qashâs al-Anbiyâ' dalam Al-Qur'an, (Surabaya: Bungkul Indah, 1985), 90.

16 Muhammad 'Ali ash-Shâbûnî, Para Nabi dalam Al-Qur'an, disadur oleh Muhammad Chirzin, (Yogyakarta: Adi Wacana, 2001), h. 58.

17 Sâmi' bin 'Abdullah al-Maghlouth, Atlas Sejarah Para Nabi dan Rasul: Menggali Nilai-Nilai Kehidupan Para Utusan, terj. Qasim Shaleh dan Dewi Kournia Sari, (Jakarta: Almahira, 2011), h. 94.

18 H.M.H. Al-Hamid Al-Husaini, Riwayat Kehidupan Nabi Besar Muhammad saw., (Jakarta: Waqfiyyah Al-Hamid Al-Husaini Press, tth), h. 103

19 Iqbal Harahap, Ibrâhîm as. Bapak Semua Agama: Sebuah Rekontruksi Sejarah Kenabian Ibrâhîm as Sebagaimana Tertuang dalam Taurat, Injil dan Al-Qur'an, (Tangerang: Lentera Hati, 2014), h. 39-40.

20 M. Ahmad Jadul Mawla dan M. Abu Al-Fadhl Ibrâhîm, Buku Induk Kisah-kisah Al-Qur'an, diterjemahkan oleh Abdurrahman Assegaf, (Jakarta: Zaman, 2009), h. 73.

21 Afîf 'Abdul Fatâh Thabbarah, Nabi-Nabi dalam Al-Qur'an, terj. Tamyiez Dery dkk (Semarang: Toha Putra, 1985), h. 163.

22 Abû Ja'far Muhammad bin Jarîr at-Thabarî, Jamî’ al-Bayân fî̀ Tafsîr Al-Qur'ân, (Beirut: Dâr alMa’rifah, $1412 \mathrm{H})$ Jil. 7, h. 158.

23 Ath-Thabarî, Jamî̀ al-Bayân fî Tafsîr Al-Qur'ân, h. 158-159.

24 Ath-Thabarî, Jamî̀ al-Bayân fî̀ Tafsîr Al-Qur'ân, h. 158. 
Nâshir Makârim asy-Syîrâzi juga mengatakan bahwa sebagian mufasir dari kalangan Ahlussunah berpendapat bahwa Âzar adalah ayah hakiki Ibrâhîm. Sedangkan kalangan mufasir Syi'ah semuanya berpandangan bahwa Âzar bukanlah ayah Ibrâhîm. Sebagian ada yang berpendapat bahwa ia adalah kakek dari ibu Ibrâhîm, dan mayoritas berpendapat bahwa Âzar adalah paman Ibrâhîm. ${ }^{25}$

Penggunaan perbandingan nama yang terdapat dalam Taurat dan nama yang disebutkan dalam Al-Qur'an dikomentari oleh Hisyam Thalbah yang menyebutkan bahwa Kitab Perjanjian Lama menjadi sumber satu-satunya berkaitan dengan kehidupan Ibrâhîm. Namun, banyak diantara riwayat yang terkandung di dalamnya tidak bisa dipertanggungjawabkan. ${ }^{26}$

Ali ash-Shâbûnî mengkritik pandangan yang beranggapan bahwa nama Tarih adalah nama ayah Ibrâhîm dan Âzar adalah paman Ibrâhîm berdasarkan catatan Taurat, yang memang tidak bisa dipercaya, karena sumber Taurat sendiri telah diselewengkan, meski pandangan ini banyak diikuti oleh kalangan mufasir. Menurutnya, nama yang terdapat dalam Al-Qur'an adalah pendapat yang benar dan terpercaya. ${ }^{27}$

\section{PENGERTIAN WÂLID DAN $A B$ SERTA PENGGUNAANNYA DALAM AL-QUR'AN}

Kaitannya dengan kisah dialog Ibrâhîm dengan Âzar, Al-Qur'an menggunakan dua kata tunjuk untuk menyebutkan identitas Âzar yaitu kata dan. Dua redaksi kata ini ikut andil dalam menciptakan perbedaan pandangan diantara para mufasir dalam menyikapi identitias sosok Âzar. Dua kata tunjuk yang dipahami digunakan untuk lawan bicara Ibrâhîm yang memiliki hubungan kerabat.

Secara bahasa, menurut Al-Ishfahânî, kata $a b$ digunakan untuk segala sesuatu yang menjadi sebab setiap orang mendapatkan sesuatu atau mendapatkan kebaikan. Oleh sebab itu, Nabi disebut juga sebagai ayahnya (QS. Al-Ahzzâb [33]: 6). ${ }^{28}$ Sedangkan menurut Ibn Fâris, kata $a b$ digunakan untuk orang yang mendidik dan memberi makan. ${ }^{29} \mathrm{Al}-\mathrm{Musthafâwî}$ juga menyimpulkan bahwa makna tunggal dari kata $a b$ adalah pemelihara, baik dalam bentuk materi maupun non-materi, karena pada realitanya kata $a b$ ini bisa digunakan untuk menunjuk orang tua, Tuhan, guru, nabi, kakek, paman, dan selain mereka. ${ }^{30}$

Secara umum, kata $a b$ digunakan untuk menunjukan orang yang sangat dekat dan berperan penting dalam kehidupan seorang anak. Selain itu, kata $a b$ bisa juga disambung atau dikaitkan dengan nama keluarga, anak, hewan, benda dan sifat manusia, misalnya

25 Nâshir Makârim Shîrâzî, al-Amtsâl fî Tafsîr Kitâbillâh al-Munazzal, (Qûm: Mansyûrat Madrasah al-Imâm 'Alî bin Abî Thâlib (A), 1421 H) Jil. 4, h. 343.

26 Hisham Thalbah (et.al), Ensiklopedia Mukjizat Al-Qur'an dan Hadis, terj. Syarif Hade Masyah (et.al) (Tt: Sapta Sentosa, 2009) Jil. 1, h. 63.

27 Muhammad 'Ali ash-Shâbûnî, Kisah-Kisah Nabi dan Masalah Kenabian, terj. Muslich Shabir (Semarang: Cahaya Indah, 1994), h. 222.

28 Ar-Raghib al-Ishfahânî, Mufradat Alfâzh Al-Qur'an, tahqîq Shafwan Adnân Dawûdi, (Damaskus: Dâr al-Qalam, 1430 H/2009 M), h. 57.

29 Abi Husain Ahmad bin Fâris bin Zakariyâ, Muıjam Maqâyis al-Lughah, tahqî̀ Abd al-Salâm Muhammad Harun, (Libanon: Dâr al-Islâmiyah, 1410 H/1990 M) Jil. 1, h. 44.

30 Al-Musthafâwî, at-Tahqîq fî Kalimât Al-Qur'ân al-Karîm (Teheran: Markâz Nasyr Asar alAlamah al-Musthafâwî, 1385) Jil. 1, 30 
Abû Hasan, Abû Hurairah dan Abû Jahal.Sementara mengenai kata al-wâlid, al-Fayûmîn ${ }^{11}$ dan Ibn Mandzûr ${ }^{32}$ mengatakan bahwa kata tersebut memiliki makna yang sama dengan kata $a l-a b$.

Al-Qur'an menggunakan kata $a b$ untuk menyebutkan paman, dan dalam bentuk jamaknya dapat bermakna nenek moyang (QS. Al-Baqarah [2]: 133). Ayat tersebut menurut Khairul Muttaqin menunjukkan bahwa penggunaan kata $a b$ dalam Al-Qur'an tidak selalu bermakna ayah kandung, tetapi bisa juga bermakna lain yaitu paman, kakek, bahkan ayah tiri. ${ }^{33}$

Asy-Sya'râwî ketika menjelaskan QS. al-An'âm [6]: 74 menyebutkan bahwa bila setelah kalimat li abîhi disebutkan nama seseorang, dalam hal ini yang dimaksud adalah Âzar, maka ayat tersebut menunjukkan bahwa identitas Âzar adalah paman Ibrâhîm. ${ }^{34}$ Namun, pada ayat lain kata $a b$ digunakan juga untuk menunjukkan identitas ayah kandung, sebagaimana Al-Qur'an menceritakan mengenai dialog antara Yûsuf dengan Yá qûb (QS. Yûsuf [12]: 4).

Untuk kata al-wâlid digunakan oleh Ibrâhîm saat ia mencoba untuk memohonkan ampun bagi 'orang tuanya' yaitu pada QS. Ibrâhîm [14]: 14. Kata dan konteks yang sama yaitu doa pengampunan untuk 'orang tua' juga pernah diucapkan sebelumnya oleh Nuh (QS. Nûh [71]: 28).

\section{DALIL KESUCIAN NASAB DAN RIWAYAT KONDISI ÂZAR}

Perdebatan mengenai identitas Âzar dikalangan para teolog dan mufasir, tidak bisa dipisahkan dari adanya beberapa riwayat yang menyatakan bahwa nasab para nabi terjaga dan suci. Pembahasan mengenai riwayat ini misalnya saja disebutkan oleh as-Suyuthi, al-Jawzi, al-Ashbihâni dan an-Nabhâni. Di sisi lain juga terdapat riwayat mengenai Nur Muhammad yang berpindah dari generasi ke generasi, misalnya saja riwayat dari Ibn 'Abbâs yang menyatakan bahwa nur Muhammad yang tercipta sebelum Adam terus berpindah dari tulang rusuk yang suci ke rahim yang suci. ${ }^{35}$

Bahkan, Ibrâhîm al-Baijuri berkesimpulan terkait dengan hadis di atas yang menandakan bahwa nenek moyang Nabi Muhammad sampai ke Adam dan Hawa tidak ada yang kafir. ${ }^{36}$ Dalil kesucian nasab dan nur Muhammad inilah yang dijadikan pegangan bagi kelompok yang menyatakan bahwa tidak ada dari leluhur para nabi yang kafir, karena itu Âzar bagi

31 Ahmad bin Muhammad bin Ali al-Fayûmi al-Muqri, al-Mishbâh al-Munîr: Mu'jam 'Arabi, (Beirut: Maktabah Lubnân, 1987 M), 257.

32 Ibn Mandzûr, Lisân al-'Arab, (Kairo: Dâr al-Hadîs, 1434 H/2013 M), Jil. 9, h. 397.

33 Khairul Muttaqin, "Keislaman Ayah Nabi Ibrahim (Studi Analisis Tafsir dan Hadits Nabi tentang Agama Ayah Nabi Ibrahim as)," El-Furqania, Vol. 5, (Desember 2017), h. 201.

34 Muhammad Mutawalî asy-Sya'râwî, Qishash al-Anbiyâ' wa ma'ahâ Sîrah ar-Rasîl, tahqîq Ibrâhîm 'Abd as-Sattâr 'Alî dan Muhammad Samîh 'Umar (t.tp: Dâr al-Qudûs, 1426 H/2006 M), h. 81-82.

35 'Abdurrahmân Ad-Dibâ'i, Terjemah Dibai (Riwayat Kelahiran Nabi saw.), terj. Redaksi, (Semarang: Karya Toha Putra, 2007), h. 38-40. Lihat juga, Muhammad Nawawî bin Umar bin Arabi, Fath ash-Shamad al-Alâm 'ala Maulîd asy-Syaikh Ahmad bin al-Qâsim al-Bulûgh al-Fauz li Bayân alLafzh Maulîd Ibn al-Jauzi, (Surabaya: Syirkat Piramid, tth), h. 11. Lihat juga, 'Abbas bin Muhaimîd, al-Bunyân al-Manshîsh fî Syarh al-Maulîd al-Manqûsh, (Istanbul: Maktabah al-Hakîkat, 1333 H/2012 M), h. 129.

36 Ibrâhîm al-Baijûri, Tahqîq al-Maqâm 'ala Kifâyah al-'Awwâm fî̀ mâ Yajibu Alaihi al-Kalâm (Indonesia: Dâr Ihyâ’ al-Kutub al-'Arabiyyah, t.th), h. 79.

6 I Al-Fanar: Jurnal Ilmu Al-Qur'an dan Tafsir 
kelompok ini bukanlah ayah kandung Ibrâhîm. Namun, kelompok lain yang menyatakan bahwa Âzar adalah ayah kandung Ibrâhîm juga beralasan dengan menggunakan dalil riwayat lainnya yaitu riwayat mengenai kondisi Âzar.

Bukhârî dalam kitabnya menyebutkan tiga buah hadis mengenai kondisi Âzar melalui tiga jalur yaitu Ismầîl bin 'Abdullah, ${ }^{37}$ Ibrâhîm bin Thamhân, dan Sa'îd al-Maqbarî̀ yang ketiganya bersumber kepada Abî Hurairah. Hadis riwayat Bukhârî ini juga dikutip ulang oleh para Muhadditsîn lain, seperti Daruquthnî̀ ${ }^{39}$ dan al-Baihaqî. ${ }^{40}$

Al-Bazzâr meriwayatkan dua buah hadis mengenai kondisi Âzar melalui jalur Ahmad bin Miqdam sampai kepada Abi Sa’id al-Khudri ${ }^{41}$ dan dari jalur Maimûn sampai kepada Abî Hurairah. ${ }^{42}$ Sementara an-Nasầî meriwayatkan hadis mengenai kondisi Âzar melalui jalur Ahmad bin Hafsh sampai kepada Abî Hurairah. ${ }^{43}$ Sedangkan Al-Hâakim meriwayatkan tiga buah hadis mengenai kondisi Âzar melalui jalur 'Alî bin Hamashad sampai kepada Abî Hurairah, ${ }^{44}$ Abû Zakariyya Yahya bin Muhammad al-Anbârî sampai kepada Abî Sa'id alKhudrî ${ }^{45}$ dan dari jalur Abû al-Qâsim 'Abdurrahmân sampai kepada Abî Hurairah. ${ }^{46}$ Dan yang terakhir adalah Abî Ya'la, yang meriwayatkan hadis mengenai kondisi Âzar melalui jalur Ahmad bin Miqdâm sampai kepada Abî Sa'id al-Khudrî. ${ }^{47}$

\section{SOSOK INDIVIDU ÂZAR}

Pandangan atau perdebatan mengenai identitas Âzar yang terjadi pada masa klasik ternyata ikut mempengaruhi para Mufassir Nusantara dalam menafsirkan ayat-ayat dialog Ibrâhîm dan Âzar. Mengenai identitas Âzar, Muhammad Nawawi al-Bantani dalam Tafsir Marah Labîd menjelaskan sebagai berikut:

"Âzar adalah ayah Ibrâhîm, di dalam Taurat ia memiliki dua nama salah satunya adalah Tarah." 48

37 Abû 'Abdillah Muhammad Ibn Ismầîl bin Ibrâhîm Ibn Mughîrah al-Bukhâri, Shahîh alBukhârî, (t.tp.: Dâr al-Fikr, 1981) Jil. 4, h. 110.

38 Al-Bukhâri, Shahîh al-Bukhârî, Jil. 6, h. 16. No. Hadis 4768-4769.

39 'Alî bin 'Umar bin Ahmad bin Mahdi ad-Daruquthni, al-Alzamât wa at-Tathabba, tahqîq Abû 'Abd al-Rahmân Muqbil bin Hâwi al-Warâ ì (Beirut: Dâr al-Kutub al-'Ilmiyyah, 1405 H/1985 M) Hadis No. 16, h. 137-138.

40 Ad-Daruquthni, al-Alzamât wa at-Tathabba Hadis No. 16, 137-138.

41 Nur ad-Dîn 'Alî bin Abî Bakar al-Haisamî, Kasyf al-Astâr 'an Zawâid al-Bazzar 'ala al-Kutub asSittah, tahqîq Habîb al-Rahmân al-'Azhami (Beirut: Muasasah al-Risâlah, 1399 H/1979 M) Jil. 1, Hadis No. 94, 65 .

42 Al-Haisamî, Kasyf al-Astâr, Jil. 1, Hadis No. 97, 66.

43 'Abd ar-Rahman Ahmad bin Syuaib al-Nasâ'i, as-Sunan al-Kubrâ, diedit oleh Hasan Abd alMun'im Syalbi (Beirut: Muasasah al-Risâlah, 1421 H/2001 M) Jil. 10, Hadis No. 11311, 206-207.

44 Muhammad bin 'Abdullah al-Hâkim an-Naisabûri, al-Mustadrak 'Ala ash-Shahîhain, diedit oleh Musthafa 'Abd al-Qâdir Atha, (Beirut: Dâr al-Kutub al-'Ilmiyyah, 1422 H/2002 M) Jil. 2, Hadis No. 2936, 260.

45 Al-Hâkim, al-Mustadrak, Jil. 4, h. 63, No. Hadis 8746.

46 Al-Hâkim, al-Mustadrak, Jil. 4, h. 632, No. Hadis 8750.

47 Ahmad bin 'Ali bin al-Mutsana at-Tamîmî,Musnad Abî Ya'lâ, diedit oleh Husain Salîm Asad (Beirut: Dâr al-Ma'mûn li Turâts, 1410 H/1990 M) Jil. 2, h. 533, No. Hadis 1406.

48 Muhammad Nawâwî al-Jâwî, Marâh Labîd, (Surabaya: Dar al-Ilm, tth) Jil. 1, h. 246. 
Dari penafsiran tersebut, secara tidak langsung Nawawi mengakui bahwa Âzar adalah bapak kandung Nabi Ibrâhîm. Nawawi juga menyatakan bahwa Âzar yang disebutkan Al-Qur'an dan Tarih yang disebut Taurat adalah satu orang. Karena itu, pada tafsiran di ayat lainnya, Nawawi tetap menggunakan kata "abîhi” yang jika dihubungkan dengan penafsirannya di atas, maka makna kata "abîhi" pada penafsiran ayat yang lain juga bermakna Âzar sebagai ayah kandung Ibrâhîm.

Tetapi, saat menafsirkan QS. at-Taubah ayat 114 dan mengkaitkan ayat tersebut dengan konteks kisah istighfâr Nabi Muhammad untuk Abu Thâlib, Nawawi justru menggunakan redaksi kata 'am (paman) untuk Âzar. Padahal, pada baris sebelumnya dalam tafsiran ayat itu, Nawawi menggunakan kata abîhi untuk mmenunjukkan identitas Âzar. Berikut penafsiran Nawawi:

"Sesungguhnya paman Ibrâhîm yaitu Âzar adalah orang yang menjadikan berhala sebagai tuhannya." ${ }^{49}$

Pernyataan Nawawi pada QS. at-Taubah ayat 114 telah menegasikan pernyataan sebelumnya pada QS. al-An'Âm [6]: 74. Penafsirannya yang berubah dapat dipahami sebagai bentuk pembelaannya terhadap persoalan status paman Nabi Muhammad, yaitu Abu Thâlib. Jika sebelumnya seolah-olah Nawawi mengakui Âzar sebagai ayah kandung Ibrâhîm hingga penggunaan kata "abîhi" pada ayat-ayat yang lain dapat dimaknai oleh para pembaca seperti itu pula, ternyata dengan pernyataan dan penggunaan redaksi 'am maka sudah jelas bahwa Nawawi beranggapan bahwa Âzar adalah paman Ibrâhîm bukan ayah kandungnya. Karena itulah, meski pada ayat-ayat setelahnya Nawawi tetap menggunakan redaksi kata "abîhi", pembaca dapat memahami bahwa yang dimaksud kata tersebut adalah paman.

Hasbi dalam Tafsir an-Nûr menyatakan bahwa Âzar adalah ayah dari Nabi Ibrâhîm as. Kesimpulan ini dapat dilihat dari kekonsistenan Hasbi yang menggunakan redaksi kata "ayah" yang melekat bagi sosok Âzar. Meskipun memang tidak secara eksplisit Hasbi menyebut Âzar sebagai ayah kandung Ibrâhîm, tetapi melalui penafsirannya yang lebih banyak berupa dialog antara Ibrâhîm dengan Âzar yang menggunakan redaksi kata 'ayah', misalnya pada dialog Ibrâhîm kepada Âzar, saat Âzar menolak ajakan Ibrâhîm pada QS. Maryam: 47:

"Walau ayah menampik nasihatku dan menolak ajuranku, aku tetap anak ayah. Aku pun tetap memohonkan ampunan ayah kepada Tuhanku. Semoga Allah memberikan taufik kepada ayah untuk memperoleh petunjuk dan semoga Allah memberi penerangan matahati sehingga ayah mau menerima kebenaran." 50

Berkaitan dengan persoalan identitas Âzar, Hamka menyoroti para mufasir yang menyebutkan bahwa Tarah adalah ayah atau nama lain bagi ayah Ibrâhîm. Adanya anggapan yang dipakai para mufasir itu menurut Hamka tidak lepas dari pengaruh Yahudi dan Nasrani yang menganggap bahwa nama Âzar yang tertera dalam Al-Qur'an tidak sesuai dengan yang tercatat dalam kitab mereka. Hamka justru menegaskan agar umat Muslim tetap berpegang pada apa yang disebutkan dalam Al-Qur'an.

Selanjutnya disebut nama ayah Ibrâhîm ialah Âzar. Sedang yang masyhur dalam sejarah nama ayah Ibrâhîm ialah Tarah. Ahli-ahli tafsir yang besar-besar selalu juga menyebut Tarah itu. Setengah mereka mengatakan bahwa Âzar adalah gelar

49 Nawâwî al-Jâwî, Marâh Labîd, Jil. 1, h. 357.

50 Teungku Muhammad Hasbi ash-Shiddieqy, Tafsir Al-Qur'an al-Majid an-Nur, (Semarang: Pustaka Rizki Putra, 2000) Vol. 3, h. 2483. 
atau panggilan lain bagi ayah Ibrâhîm. Janganlah kita heran, dan jangan kita kena bujuk rayu dari pemeluk Yahudi dan Nasrani yang sengaja hendak menyalahkan Al-Qur'an atau memalsukannya, karena nama itu tidak cocok dengan apa yang ada dalam catatan mereka. ${ }^{51}$

Hamka juga konsisten menggunakan redaksi kata 'ayah' dalam setiap tafsirnya yang berkaitan dengan dialog Ibrâhîm dengan Âzar. Saat menjelaskan QS. Maryam: 42, Hamka menyatakan bahwa pemilihan kata yang digunakan dalam ucapan Ibrâhîm kepada Âzar adalah memberikan komentar mengenai redaksi "yâ abâtì yang digunakan oleh Al-Qur'an merupakan kata yang sangat halus dan mengandung makna penghormatan. Ibrâhîm menurutnya tidak menggunakan ungkapan kata "wâlid" dan “abì" yang sebenarnya memiliki makna yang sama. Penggunaan redaksi kata menurut Hamka memiliki arti yang sama. Pemilihan redaksi “yâ abâtì merupakan bagian dari fashâhat Al-Qur'an.

“Seketika dia berkata kepada ayahnya: 'Wahai ayahku!' (pangkal ayat 42). Bahasa yang dipakai Tuhan dalam wahyu kepada Nabi Muhammad saw. ini ketika mengkisahkan Ibrâhîm menghadapkan kata kepada ayahnya ialah: 'yâ abâti! Yaitu kita artikan 'Wahai ayahku!' Bahasa ini halus dan penuh hormat. Tidak diucapkan 'yâ wâlidi', atau 'yâ ab̂̀', padahal artinya pun sama. Disinilah tersimpan fashâhat AlQur'an, yaitu memilih kalimat yang indah untuk disusun menjadi kalam."52

Thaba'thaba'î terkait penggunaan kata wâlid dan $a b$.

Terlepas dari perbedaan pendapat ulama menyangkut hal ini, apa yang dikemukakan oleh penafsir Syiah, Thaba'thaba' î, sangat wajar untuk dipertimbangkan. Menurutnya, Al-Qur'an menggunakan kata wâlid untuk makna ayah kandung, sedang kata $a b$ digunakan Al-Qur'an untuk makna kakek atau paman dan lain-lain (baca antara lain, QS. al-Baqarah [2]: 133, Yûsuf [12]: 38). Hemat penulis, apa yang dikemukakan di atas benar adanya-tetapi perlu dicatat bahwa Al-Qur'an menggunakan juga kata $a b$ untuk menunjuk orangtua kandung, misalnya QS. Yûsuf [12]: 4 (idz qâla ŷusuf li abîhi). Di sisi lain, perlu juga dicatat bahwa merujuk kepada Al-Qur'an Nabi Ibrâhîm as. menggunakan kedua kata tersebut. Dalam QS. Ibrâhîm [14]: 41, beliau menggunakan kata wâlidayya untuk menunjuk kepada ibu bapaknya. AsySya'rawî dalam tafsirnya, setelah membuktikan bahwa kata $a b$ digunakan untuk menunjuk ayah kandung atau paman, mengemukakan bahwa biasanya bila kata $a b$ dirangkaikan dengan namanya, yang dimaksud adalah selain ayah kandung. Kalau ada yang bertanya ke mana ayah kandung seseorang, cukup sudah jika ia bertanya: Kemana ayahmu? Tetapi, kalau yang ditanyakan selain ayah kandung, di sini pertanyaan harus disertakan dengan nama yang bersangkutan. Nah, ayat ini menggunakan kata ab/ayah sambil menyebut nama, yakni Âzar. Dengan demikian, yang bersangkutan bukan ayah kandung Nabi Ibrâhîm. ${ }^{53}$

Pada saat menafsirkan ayat lainnya, sikap Quraish masih belum terlalu jelas. Meski pada kutipan di atas secara eksplisit sebenarnya Quraish mengikuti padangan asy-Sya'rawî yang menyatakan bahwa Âzar bukan ayah kandung Ibrâhîm. Tetapi, saat menafsirkan QS. Maryam [19]: 2, Quraish masih kebingungan dengan pandangan asy-Sya'rawî yang belum jelas baginya karena pandangan asy-Sya'rawî mengenai konteks ayat ini belum dijumpai Quraish.

51 Hamka, Tafsir Al-Azhar, (Singapura: Pustaka Nasional PTE LTD, 2003) Vol. h. 2078.

52 Hamka, Tafsir Al-Azhar, Vol. 6, h. 4310-4311.

53 Quraish Shihab, Tafsir Al-Misbah: Pesan, Kesan, dan Keserasian Al-Qur'an, (Jakarta: Lentera Hati, Perpustakaan Umum Islam Iman Jama dan Paguyuban Yayasan Al-Ikhas, 2012), Vol. 3, h. 507. Saat menjelaskan QS. Maryam [19]: 42 Quraish juga kembali menyebutkan dua pandangan ini. 
"Demikian tulis ulama Mesir itu ketika menafsirkan ayat al-An'âm. Apakah ini berarti bahwa yang dimaksud dengan abîhi pada ayat surah Maryam ini adalah ayah kandung Nabi Ibrâhîm as. Karena kata tersebut tidak dirangkaikan dengan namanya — seperti dalam surah al-An'âm—tidak jelas bagi penulis karena hinggga penafsiran surah ini penulis siapkan, tafsir ash-Sha'rawi untuk surah ini belum terbit." ${ }^{4}$

Kenyataannya, sikap Quraish Shihab yang memberikan komentar dan menyisihkan berbagai pandangan para mufassir lainnya dalam rangka untuk menengahi kedua pandangan mengenai sosok Âzar. Quraish berusaha mengakomodir kedua pandangan itu dan berusaha berada di tengah-tengah dan tidak terlibat lebih jauh dalam perdebatan. Alasan itu yang menjadi faktor Quraish memilih menerjemahkan kata abîhi sebagai orangtua yang dianggapnya netral, bukan ayah atau bapak.

"Kata abîhi secara harfiah berarti ayahnya, namun di sini dan ayat-ayat serupa, penulis terjemahkan dengan orangtuanya. Ini hemat penulis adalah kata yang netral, menghadapi perbedaan pendapat ulama apakah yang dimaksud di sini adalah orang tua kandungnya atau orang lain yang diperlakukan sebagai ayahnya. Secara panjang lebar, persoalan tentang orangtua Nabi Ibrâhîm penulis telah uraikan ketika menafsirkan QS. Al-An'âm [6]: 74. Rujuklah ke sana." ${ }^{5}$

Usaha Quraish untuk netral memang lebih dominan karena sering ia tekankan, meski pada beberapa terjemahan ia juga menggunakan redaksi kata 'bapak' untuk menunjuk lawan bicara Ibrâhîm dalam konteks identitas Âzar dan cenderung menganggap bahwa Âzar adalah paman Ibrâhîm. Indikasi ini bisa dilihat dari ajakannya agar pembaca merujuk pandangannya mengenai sosok Âzar saat menafsirkan QS. Al-An'âm [6]: 74 dan ini dilakukan berkali-kali. Quraish juga lebih banyak menghadirkan pandangan para mufasir yang menolak Âzar sebagai ayah Ibrâhîm.

Sementara itu, Tafsir Kementerian Agama menafsirkan sosok Âzar sebagai ayah Ibrâhîm. Kesimpulan ini bisa terlihat dari pandangan yang dikutip dalam tafsir ini terkait dengan QS. Ibrâhîm [14]: 41

"Ibrâhîm as. berdoa agar Allah mengampuni segala kesalahannya, kesalahan ibubapaknya, dan kesalahan orang-orang yang beriman pada hari dimana Allah menghimpun mereka untuk dihisab segala amal dan perbuatannya yang telah dikerjakan semasa hidup di dunia dahulu. Diriwayatkan dari al-Hasan bahwa ibu Ibrâhîm adalah seorang yang beriman kepada Allah, sedang bapaknya adalah orang yang kafir. Ia memohonkan ampun bagi bapaknya itu karena ia pernah berjanji akan memohon ampun bagi bapaknya. Akan tetapi, tatkala ternyata bapaknya tetap dalam kekafirannya dan menjadi musuh Allah, maka ia berlepas diri darinya." 56

Dari kutipan tersebut jelas dipahami bahwa Tafsir Kemenag menganggap bahwa Âzar adalah ayah Ibrâhîm dan Âzar termasuk golongan orang kafir. Akan tetapi, pengutipan riwayat yang digunakan Tafsir Kemenag tidak disebutkan secara jelas sumber dan sanadnya, sehingga para pembaca tidak dapat mengetahui lebih jelas mengenai status dan sanad dari riwayat itu sendiri. Sosok Âzar dalam Tafsir Kemenag juga lebih banyak dilabeli dengan kata 'bapak' dan 'ayah'.

54 Quraish Shihab, Tafsir Al-Misbah, Vol. 7, h. 460.

55 Quraish Shihab, Tafsir Al-Misbah, Vol. 9, h. 249.

56 Kementerian Agama RI, Al-Qur'an dan Tafsirnya (Edisi yang Disempurnakan), (Jakarta: Lentera Abadi, 2010) Vol. 5, 179. 
Egi Sukma Baihaki

\begin{tabular}{|c|c|c|}
\hline Judul Kitab & $\begin{array}{l}\text { Penggunaan } \\
\text { Kata }\end{array}$ & Tempat \\
\hline \multirow{2}{*}{$\begin{array}{l}\text { Tafsir Marah } \\
\text { Labid }\end{array}$} & $A b$ & $\begin{array}{l}\text { QS. al-An'âm [6]: 74; QS. at-Taubah [9]: 114; dan } \\
\text { QS. al-Mumtahanah [60]: } 4 .\end{array}$ \\
\hline & $A m$ & QS. at-Taubah: 114. \\
\hline \multirow[t]{2}{*}{ Tafsir An-Nur } & Ayah & $\begin{array}{l}\text { QS. al-An'âm [6]: 74; QS. at-Taubah [9]: 114; QS. } \\
\text { Ibrâhîm [14]: 41; QS. Maryam [19]: } 42 \text { dan 47; QS. } \\
\text { al-Anbiyầ [21]: 52; QS. asy-Syu'arâ [26]: } 70 \text { dan 86; } \\
\text { QS. ash-Shaffât [37]: 85; QS. az-Zukhrûf [43]: } 26 \\
\text { dan QS. al-Mumtahanah [60]: } 4 .\end{array}$ \\
\hline & Bapak & QS. Ibrâhîm: 41. \\
\hline \multirow[t]{2}{*}{ Tafsir Al-Azhar } & Ayah & $\begin{array}{l}\text { QS. al-An'âm [6]: 74; QS. at-Taubah [9]: 114; QS. } \\
\text { Maryam [19]: } 42 \text { dan 47; QS. al-Anbiyâ [21]: 52; } \\
\text { QS. asy-Syu'arâ [26]: } 70 \text { dan 86; QS. ash-Shaffât } \\
\text { [37]: 85; dan QS. al-Mumtahanah [60]: 4. }\end{array}$ \\
\hline & Bapak & QS. Ibrâhîm: 41 dan QS. Az-Zukhrûf [43]: 26. \\
\hline \multirow[t]{3}{*}{ Tafsir Misbah } & Orangtua & $\begin{array}{l}\text { QS. Al-An'âm [6]: 74; QS. Ibrâhîm [14]: 41; QS. } \\
\text { Maryam [19]: 42; QS. al-Anbiyầ [21]: 52; QS. asy- } \\
\text { Syu'arâ [26]: 70 dan 86; QS. ash-Shaffât [37]: 85; } \\
\text { az-Zukhrûf [43]: } 26 \text { dan QS. al-Mumtahanah: } 4 \text {. }\end{array}$ \\
\hline & Bapak & QS. at-Taubah [9]:114 dan QS. Maryam [19] 47. \\
\hline & Paman & QS. at-Taubah [9]: 114. \\
\hline \multirow[b]{2}{*}{$\begin{array}{l}\text { Al-Qur'an dan } \\
\text { Tafsirnya }\end{array}$} & Ayah & QS. al-Anbiyâ [21]: 52. \\
\hline & Bapak & $\begin{array}{l}\text { QS. al-An'âm [6]: 74; QS. Ibrâhîm [14]: 41; QS. } \\
\text { Maryam [19]: 47; QS. al-Anbiyâ [21]: 52; QS. asy- } \\
\text { Syưarâ’ [26]: } 70 \text { dan } 86 \text { dan az-Zukhrûf [43]: } 26 .\end{array}$ \\
\hline
\end{tabular}

\section{Tabel Penggunaan Kata Tunjuk Identitas Âzar dalam Tafsir Nusantara}

Dari tabel tersebut dapat dilihat bahwa hanyaTafsir Munir yang berbahasa Arab dan menggunakan dua redaksi kata tunjuk untuk dialog Ibrâhîm dengan Âzar yaitu kata $A b$ dan Am. Sedangkan sisanya adalah Tafsir berbahasa Indonesia atau Melayu yang lebih banyak menggunakan tiga kata yang harus diperjelas penggunaannya secara kaidah bahasa yaitu kata ayah, bapak, dan orangtua. Kata paman sendiri memang digunakan, tapi saat kata itu dituliskan atau diucapkan, pendengar atau pembaca akan langsung bisa menangkap maksud kata tersebut, berbeda dengan tiga kata itu. Pemilihan kata yang baik sangat penting dalam menentukan maksud yang dituju oleh seorang mufasir. Pemilihan kata juga akan mencerminkan dan mempengaruhi pandangan mufasir. Alasan adanya perbedaan penerjemahan kata ini juga menjadi sebab mengapa Quraish memilih menggunakan kata "orangtua” yang dianggap Quraish bersifat netral.

Jika kita merujuk pada KBBI, kata ayah bisa digunakan untuk semua orang tidak 
hanya orangtua kandung, tapi bisa paman atau orang yang dihormati. Kata 'bapak' sendiri hanya bisa digunakan untuk orangtua kandung seseorang. Sedangkan kata orangtua bisa digunakan untuk menyebut orangtua kandung atau orang lain yang dihormati. ${ }^{57}$

\begin{tabular}{|c|c|}
\hline Judul Tafsir & Idenitas Âzar \\
\hline Tafsir Marah Labid & Paman \\
\hline Tafsir An-Nur & Bapak Kandung \\
\hline Tafsir Al-Azhar & Bapak Kandung \\
\hline Tafsir Misbah & Paman \\
\hline Al-Qur'andan Tafsirnya & Bapak Kandung \\
\hline
\end{tabular}

Tabel Tentang Identitas Âzar

Dilihat dari penggunaan ketiga kata dengan realita penggunaanya pada tafsir Nusantara, tampak bahwa Bahasa Indonesia tidak sepenuhnya dapat mengakomodir bahasa serapan bahasa Arab yang setiap katanya dapat memiliki makna lebih dari satu. Faktor ini ikut memengaruhi adanya perbedaan penafsiran mufassir Nusantara dalam memilih dan menggunakan redaksi kata untuk menjelaskan identitas Âzar.

\section{KONSEKUENSI TEOLOGIS PENAFSIRAN}

Penafsiran identitas Âzar memang memiliki konsekuensi teologis dengan konsep kesucian nasab para nabi. Sebagian mufassir Nusantara ada yang secara jelas menyinggung persoalan kesucian nasab ini, tetapi ada juga yang tidak. Meski secara jelas para mufassir Nusantara tidak menyinggung persoalan kesucian nasab, tetapi pandangan mereka mengenai sosok dan identitas Âzar akan mencerminkan pandangan atau respon mereka terhadap persoalan kesucian nasab nabi.

Nawawi dalam Marâh Labid, saat menjelaskan bahwa Âzar adalah bapak Ibrâhîm, ia juga menafsirkan bahwa Nur Muhammad dari para leluhurnya (sejak Adam hingga Abdullah) akan berpindah kepada istri. Sehingga, meski setelah perpindahan itu suami atau ayah para nabi melakukan tindakan kekafiran, maka tidak menjadi persoalan.

"Perlu diketahui bahwa semua nasab Rasulullah itu disucikan dari penyembahan terhadap berhala selama Nur Muhammad masih berada di dalam sulbi mereka. Adapun jika Nur itu telah berpindah dari sulbi mereka, maka bisa saja mereka melakukan penyembahan terhadap berhala dan lain sebagainya dari berbagai macam bentuk kekafiran." 58

Dari penjelasan tersebut maka secara tidak langsung Nawawi tidak mempersoalkan jika ada orangtua Nabi yang kafir. Karena, kenabian tidak berkaitan dengan ikatan keluarga dan nasab.

Saat menafsirkan QS. al-An'âm, Hamka menyinggung adanya pandangan dari mazhab Syiah yang beranggapan bahwa Âzar bukan ayah kandung Ibrâhîm. Pandangan ini menurut Hamka menguatkan pendapat yang mengakui keimanan kedua orangtua Nabi Muhammad sebagaimana berimannya kedua orangtua Ibrâhîm. Pandangan seperti ini menurut Hamka

57 Badan Pengembangan dan Pembinaan Bahasa Kementerian Pendidikan dan Kebudayaan, "Kamus Besar Bahasa Indonesia", https://kbbi.kemdikbud.go.id/entri/, diakses pada 21 Februari 2018.

58 Nawâwî al-Jâwî, Marah Labîd, Jil. 1, h. 246. 
lahir karena rasa cinta dan penghormatan kelompok tersebut kepada Nabi Muhammad. Nabi memang pernah mengatakan bahwa ia berasal dari nenek moyang yang tidak pernah melakukan perbuatan tercela. Mengenai hadis tersebut, Hamka berkomentar bahwa jika leluhur Nabi Muhammad dinyatakan terhindar dari hubungan di luar nikah, maka tidak menutup kemungkinan ada diantara mereka yang musyrik. Kecintaan kepada Nabi dan leluhurnya itu yang menjadi sebab umat tidak tega menyebut kedua orangtua Nabi Muhammad atau kedua orangtua Nabi Ibrâhîm dalam keadaan kafir.

Menarik hati juga perbincangan Ulama-ulama tafsir tentang ayah Ibrâhîm ini. Ada yang mengatakan, konon dari kalangan Mazhab Syi'ah bahwa Âzar itu bukanlah ayah Ibrâhîm, tetapi saudara ayahnya (paman). Mereka menonjolkan penafsiran begini untuk menegakan suatu pendirian bahwa ibu-bapak seorang Nabi atau Rasul tidaklah mungkin seorang kafir. Lantaran itu maka segala ayat yang berhubungan dengan kisah Ibrâhîm dengan ayahnya, selalu mereka artikan pamannya. Untuk itu pula mereka kuatkan bahwa yang ayah Ibrâhîm itu memang Tarah namanya, bukan Âzar. Pendapat itupun mempunyai ekor yang lanjut, yaitu untuk menegakkan pendapat bahwa ayah-bunda Nabi Muhammad saw. pun bukanlah kafir, tetapi Islam yang juga sebagai ayah kandung Ibrâhîm. Niscaya timbulnya pendapat atau pendirian yang begini tidak lain daripada rasa cinta dan hormat kepada Nabi-nabi jua. Apalagi Rasulullah saw. memang pernah mengatakan bahwa beliau dilahirkan ke dunia, sejak nenek-moyangnya sampai ke atas sekali yaitu Adam, tidak sekali juga nenek-neneknya yang lahir ke dunia dari hubungan di luar nikah, yang disebut: 'sifaah'. Padahal jika Rasul dari nenek-moyangnya tidak ada yang lahir di luar nikah, bukanlah berarti nenek-moyang beliau tidak ada yang tersesat menyembah berhala. Tetapi adanya pendirian yang demikian tidak pula lain dari semata-mata bebasnya perkembangan ijtihad dalam Islam. Rasa cinta kepada Rasulullah saw. dan kepada neneknya Ibrâhîm, menyebabkan orang 'tidak sampai hati' akan menyebut bahwa ibu-bapak Nabi saw. atau ibu-bapak Ibrâhîm tidak Islam, atau kafir, atau masuk neraka. ${ }^{59}$

Quraish dalam menafsirkan QS. al-An'âm [6]: 74 ia menghadirkan pandangan yang menolak Âzar sebagai ayah kandung Ibrâhîm dengan alasan kesucian nasab Nabi Muhammad yang mengutip hadis riwayat Ibn 'Adi dan at-Thabrânî melalui jalur 'Ali bin Abî Thâlib. Jika menyakini abîhi atau Âzar adalah ayah kandung Ibrâhîm, maka akan bertentangan dengan kesucian nasab para nabi. Quraish juga kembali mengutip pandangan ini saat menafsirkan QS. Maryam [19]: 42.

Salah satu alasan yang menolak memahami kata abîhi/bapaknya dalam arti bapak kandung adalah bahwa jika Âzar adalah bapak kandung Nabi Ibrâhîm as, itu berarti ada dari leluhur Nabi Muhammad yang musyrik karena beliau adalah keturunan Nabi Ibrâhîm as. Ini ditolak oleh banyak ulama dengan alasan bahwa sekian banyak riwayat yang menyatakan kebersihan dan kesucian leluhur Nabi saw. Beliau bersabda: 'Aku dilahirkan melalui pernikahan, bukan perzinaan sejak Adam hingga aku dilahirkan oleh bapak dan ibukku. Aku tidak disentuh sedikit pun oleh kotoroan Jahiliah' (HR. Ibn 'Âdi dan at-Thabrânî melalui 'Ali bin Abî Thâlib). Ini berarti bahwa tidak seorang pun dari leluhur beliau yang mempersekutukan Allah Swt., dan dengan demikian, jika memang Âzar yang membuat dan menyembah patung itu adalah ayah kandung Nabi Ibrâhîm as.—- sedang Nabi Ibrâhîm as. adalah leluhur Nabi Muhammad saw.-maka itu berarti ada leluhur beliau yang pernah mempersekutukan Allah Swt. ${ }^{60}$

59 Hamka, Tafsir al-Azhar, Vol. 3, h. 2078-2079.

60 M. Quraish Shihab, Tafsir Al-Misbah, Vol. 3, h. 506. Sama dengan QS. Maryam [19]: 42, Vol .7, h. 459. 
Alasan ini pula yang membuat Quraish berusaha menghindari perdebatan yang ada. Ia berusaha mengakomodir dan berada di tengah-tengah dengan menerjemahkan kata abîhi dalam bahasa Indonesia sebagai "orangtua” yang dianggap oleh Quraish lebih netral dalam menghadapi perbedaan pendapat yang ada sebagaimana ia sebutkan saat menafsirkan QS. asy-Syu'arâ [26]: 70 .

Dua tafsir berikutnya yaitu Tafsir an-Nur karya Hasbi dan Al-Qur'an dan Tafsirnya karya Kemenag RI, di mana secara eksplisit tidak membahas persoalan kesucian nasab, bahkan tidak ada tafsiran atau penjelasan yang menyinggung kesucian nasab. Namun, dengan keduanya menafsirkan bahwa sosok Âzar adalah ayah Ibrâhîm, maka jika dihubungkan dengan konsekuensi teologis yang ada, kedua tafsir tersebut tidak mempermasalahkan jika ada leluhur para nabi yang melakukan tindakan kemusyrikan.

\begin{tabular}{|l|l|}
\hline \multicolumn{1}{|c|}{ Judul Tafsir } & \multicolumn{1}{c|}{ Kesucian Nasab Para Nabi } \\
\hline Tafsir Marah Labid & $\begin{array}{l}\text { Memungkinkan leluhur Para Nabi ada yang } \\
\text { Kafir }\end{array}$ \\
\hline Tafsir An-Nur & Tidak berkomentar \\
\hline Tafsir Al-Azhar & $\begin{array}{l}\text { Tidak Menutup Kemungkinan ada Leluhur } \\
\text { para Nabi yang kafir. }\end{array}$ \\
\hline Tafsir Misbah & Tidak Berkomentar \\
\hline Al-Qur'an dan Tafsirnya & Tidak Berkomentar \\
\hline
\end{tabular}

Tabel Tentang Kesucian Nasab

Tabel di atas menunjukkan bahwa hanya Nawawi dan Hamka yang menyebutkan secara tegas persoalan kesucian nasab nabi. Nawawi tidak mempermasalahkan kemusyrikan leluhur para nabi dengan konsep kesucian nasab nabi, karena bagi Nawawi perpindahan nur Muhammad membuat seseorang dimungkinkan melakukan tindakan kemusyrikan setelah nur Muhammad berpindah darinya.

Hamka menyikapi persoalan kesucian nasab ini dengan menghubungkan sikap atau pandangan kalangan Syi'ah yang menganggap bahwa Âzar bukan ayah kandung Ibrâhîm, dengan alasan untuk menghormati dan menunjukkan rasa cinta kepada para Nabi. Meski demikian, Hamka tetap pada pandangannya bahwa Âzar adalah bapak Ibrâhîm, dan terkait kesucian nasab leluhur para Nabi, Hamka menegaskan bahwa yang dimaksud adalah terhindar dari kehamilan di luar nikah, tapi tidak menutup kemungkinan berdasarkan riwayat itu bahwa ada leluhur nabi yang musyrik. Quraish Shihab sendiri justru menganggap bahwa persoalan kesucian nasab inilah yang membuat para mufassir kebingungan dan serba salah dalam menempatkan diri. Alasan ini juga yang membuat Quraish mencoba menghindari perdebatan yang ada dan berusaha netral. Ia berusaha mengakomodir semua pandangan, tetapi pada kenyataannya Quraish juga cenderung termasuk dari mufassir yang menyatakan bahwa Âzar bukan ayah kandung Ibrâhîm. Sedangkan Tafsir an-Nur dan Tafsir Kemenag secara jelas memang tidak mengomentari persoalan kesucian nasab, tetapi secara tidak langsung penafsiran mereka terhadap identitas Âzar sebelumnya menentukan pandangan mereka mengenai persoalan kesucian nasab ini. 


\section{PENUTUP}

Dari pembahasan ini dapat dilihat bahwa pembahasan mengenai identitas Âzar yang ada pada masa tafsir klasik juga masuk dan masih dibahas dalam literatur tafsir Nusantara. Kaitannya dengan identitas Âzar, para mufassir Nusantara terbagi menjadi dua pandangan. Pertama, berpandangan bahwa Âzar adalah bapak kandung Ibrâhîm, yang masuk dalam pandangan pertama ini adalah Hasbi, Hamka dan Kementerian Agama RI. Kedua, berpandangan bahwa Âzar adalah paman Ibrâhîm, yang masuk dalam pandangan kedua ini adalah Nawawi dan Quraish Shihab.

Sedangkan konsekuensi teologis yang paling menonjol dari identitas Âzar adalah pembahasan mengenai kesucian nasab para nabi. Pertama, bagi mereka yang berpandangan bahwa Âzar adalah ayah kandung Ibrâhîm, maka konsekuensi teologis yang diambil adalah orangtua para Nabi tidak harus beriman. Kedua, bagi yang berpandangan bahwa Âzar adalah paman Ibrâhîm, maka konsekuensi teologis yang diambil orangtua seorang Nabi haruslah beriman. Dengan memberikan kejelasan atau penafsiran terhadap identitas Âzar, maka secara tidak langsung pandangan para mufasir Nusantara yang terbagi kedalam dua kelompok di atas juga akan terkait dengan dua konsekuensi teologis kesucian nasab Nabi ini.

\section{DAFTAR PUSTAKA}

'Abbas bin Muhaimîd, al-Bunyân al-Marshîsh fî Syarh al-Maulid al-Manqûush, Istanbul: Maktabah al-Hakîkat, 1333 H/2012 M.

Arwîsyi, 'Abdul Hakîm bin Musthafa, Al-Muntakhabât min Rasâil as-Sayyîd 'Abd al- $\underline{\text { Hakîm }}$ al-Arwâsyi 'alaihi al-Rahmat wa al-Ridwân, Istanbul: Maktabah al-Haqîqah Kitabevi, 2014.

Ashbahâni, Abi Na'îm, Dalâil an-Nubuwwah. Beirut: Dâr an-Nafâis, 1986.

Badan Pengembangan dan Pembinaan Bahasa Kementerian Pendidikan dan Kebudayaan, "Kamus Besar Bahasa Indonesia", https://kbbi.kemdikbud.go.id/entril, diakses pada 21 Februari 2018.

Baihaqi, Abî Bakr Ahmad bin Ahmad bin al-Husain, al-Bahts wa an-Nusyûr, tahqîq Amîr Ahmad Haidar, Beirut: Markaz al-Khidmah wa al-Abhâts ats-Tsaqafiyyah, 1406 H/1986 M.

Baijûri, Ibrâhîm, Tahqî̀ al-Maqâm 'ala Kifâyat al-Awwâm fî mâ Yajibu Alaihi al-Kalâm, Indonesia: Dâr Ihyầ al-Kutub al-'Arabiyyah, t.th.

Basyûni, Hamîd Ahmad al-Thâhir, Shahîh Qashâsh Al-Qur'an, Kairo: Dâr al-Hadîs, 1426 $\mathrm{H} / 2005 \mathrm{M}$.

Bisri, M. Adib dan Abdul Mujieb AS, Qishâsh al-Anbiyẩ dalam Al-Qur'an, Surabaya: Bungkul Indah, 1985.

Bukhâri, Abû 'Abdillah Muhammad Ibn Ismầil bin Ibrâhîm Ibn Mughîrah, Shahîh alBukhârî, t.tp: Dâr al-Fikr, 1981.

Daruquthni, 'Alî bin 'Umar bin Ahmad bin Mahdi, al-Alzamât wa at-Tathabba, diedit oleh Abû 'Abd al-Rahmân Muqbil bin Hâwi al-Warầi, Beirut: Dâr al-Kutub al-'Ilmiyyah, $1405 \mathrm{H} / 1985 \mathrm{M}$.

Dibầi, 'Abdurrahmân, Terjemah Dibai (Riwayat Kelahiran Nabi saw), terj. Redaksi, Semarang: Karya Toha Putra, 2007. 


\section{IDENTITAS ÂZAR DALAM LITERATUR TAFSIR NUSANTARA}

Dimshaqî, Ibn Katsir,Tafsîr Al-Qur'an al-Azhîm, Beirut: Dâr al-Fikr, 2011 M/1433 H.

Haisâmi, Nur ad-Dîn 'Alî bin Abî Bakar, Kasyf al-Astâr 'an Zawâid al-Bazzar 'ala al-Kutub al-Sittah, diedit oleh Habîb al-Rahmân al-'Azhami, Beirut: Muasasah al-Risa>lah, $1399 \mathrm{H} / 1979 \mathrm{M}$.

Hamka, Tafsir Al-Azhar, Singapura: Pustaka Nasional PTE LTD, 2003.

Harahap, Iqbal, Ibrâhîm as. Bapak Semua Agama: Sebuah Rekontruksi Sejarah Kenabian Ibrâhim as. sebagaimana Tertuang dalam Taurat, Injil, dan Al-Qur'an, Tangerang: Lentera Hati, 2014.

Husaini, Al-Hamid, Riwayat Kehidupan Nabi Besar Muhammad saw., Jakarta: Waqfiyyah AlHamid Al-Husaini Press, t.th.

Ishfahâni, Ar-Raghib, Mufradât Alfâzh Al-Qur'an, tahqî̀ Shafwân Adnân Dawûdi Damaskus: Dâr al-Qalam, 1430 H/2009 M.

Ismầîl, Muhammad Bakr, Qashâsh Al-Qur'an Min Adam 'Alaihi as-Salâm Ila Ash $\underline{h a ̂ b}$ al-Fîl, t.tp: Dâr al-Manâr, 1418 H/1997 M.

Kadar, M. Yusuf, Studi Al-Qur'an, Jakarta: Amzah, 2012.

Kementerian Agama RI, Al-Qur'an dan Tafsirnya (Edisi yang Disempurnakan), Jakarta: Lentera Abadi, 2010.

Maghlout, Sami bin 'Abdullah, Atlas Sejarah Para Nabi dan Rasul: Menggali Nilai-Nilai Kehidupan Para Utusan, terj. Qasim Shaleh dan Dewi Kournia Sari, Jakarta: Almahira, 2011.

Manzhûr, Ibn, Lisân al-Arab, Kairo: Dâr al-Hadîs, 1434 H/2013 M.

Mawla, M. Ahmad Jadul dan M. Abu Al-Fad\}l Ibrâhîm, Buku Induk Kisah-kisah Al-Qur'an, diterj. oleh Abdurrahman Assegaf, Jakarta: Zaman, 2009.

Munip, Abdul, Transmisi Pengetahuan Timur Tengah ke Indonesia: Studi Tentang Penerjemahan Buku Berbahasa Arab di Indonesia 1950-2004, Jakarta: Puslitbang Lektur Keagamaan Balitbang dan Diklat Kemenag RI, 2010.

Musthafâwi, at-Tahqî̀ fî Kalimât Al-Qur'an al-Karim, Teheran: Markâz Nashr Asar alAlâmah al-Musthafâwi, 1385.

Muttaqin, Khairul, "Keislaman Ayah Nabi Ibrâhîm (Studi Analisis Tafsir dan Hadits Nabi tentang Agama Ayah Nabi Ibrâhîm as)," El-Furqania, Vol. 5, (Desember 2017).

Muqri, Ahmad bin Muhammad bin Ali al-Fayûmi, Al-Misbâh al-Munîr: Mu’jam Arabi Arabi, Beirut: Maktabah Lubnan, 1987 M.

Nasâi, 'Abd al-Rah\}man Ahmad bin Syuaib, as-Sunan al-Kubrâ, tahqîq Hasan Abd al-Mun'im Syalbi, Beirut: Muasasah al-Risâlah, 1421 H/2001 M.

Nawawi, Muhammad, Marâh Labîd Tafsir an-Nawawi, Surabaya: Dar al-'Ilm, t.th. Fath ash-Shamad al-Alâm 'ala Maulîd asy-Syaikh Ahmad bin al-Qâsim al-Bulîgh alFauz li Bayân al-Lafzh Maulîd Ibn al-Jauzi, Surabaya: Syirkat Piramid, t.th.

Nisâbûri, Muhammad bin 'Abdullah al-Hâkim, Al-Mustadrak 'ala ash-Shahîhayn, tahqîq Musthafa 'Abd al-Qâdir Atha', Beirut: Dâr al-Kutub al-'Ilmiyyah, 1422 H/2002 M

Râzî, Muhammad bin 'Umar al-Fakhr, Mafâtinh al-Ghaib, Beirut: Dâr Ihyâ at-Turâts al-'Arabi, $1420 \mathrm{H}$.

Sahabuddin (et.al), Ensiklopedi Al-Qur'an: Kajian Kosa Kata, Tangerang: Lentera Hati, 2007. 
Sayyid, Kamal, Kisah-kisah terbaik Al-Qur'an, diterjemahkan oleh Selma Anis, Jakarta: Pustaka Zahra, 2004.

Shâbûnî, Muhammad 'Ali, Kisah-Kisah Nabi dan Masalah Kenabian, terj. Muslich Shabir, Semarang: Cahaya Indah, 1994.

, Para Nabi dalam Al-Qur'an, disadur oleh Muhammad Chirzin, Yogyakarta: Adi Wacana, 2001.

Shiddieqy, Teungku Muhammad Hasbi, Tafsir Al-Qur'an al-Majid An-Nur, Semarang: Pustaka Rizki Putra, 2000.

Shihab, M. Quraish, Tafsir Al-Misbah: Pesan, Kesan, dan Keserasian Al-Qur'an, Jakarta: Lentera Hati, 2012.

Suyuthi, Jalâluddin, Al-Itqân fi Ulumil Qur'an, terj. Farikh Marzuqi Ammar dan Imam Fauzi Ja'iz, Surabaya: PT Bina Ilmu Surabaya, t.th.

Syâfi'i, Muhammad Idrîs, Tafsîr al-Imâm asy-Syâfi'i, Tahqiq Majdi bin Manshûr bin Sayyid al-Syûrâ, Beirut: Dâr al-Kutub al-'Ilmiyyah, 2009.

Sya’râwi, Muhammad Mutawalî, Qishâsh al-Anbiyâ' wa ma'ahâ Sîrah ar-Rasûl, Tahqiq Ibrâhîm 'Abd al-Sattâr 'Alî dan Muhammad Samîh 'Umar, t.tp.: Dâr al-Qudûs, 1426 H/2006 M.

Syîrâzi, Nâshir Makârim, Al-Amtsâl fî Tafsîr Kitâbillâh al-Munazzal, Qum: Mansyûrat Madrasah al-Imâm 'Ali bin Abî Thâlib, 1421 H.

Thabari, Abû Ja'far Muhammad bin Jarîr, Jamî’ al-Bayân fî̀ Tafsîr Al-Qur’an, Beirut: Dâr alMa'rifah, $1412 \mathrm{H}$.

Thabbarah, Afif 'Abdul Fatâh, Nabi-Nabi dalam Al-Qur'an, terj. Tamyiez Dery dkk, Semarang: Toha Putra, 1985.

Tamîmi, Ahmad bin 'Ali bin al-Muthana, Musnad Ab̂̂ Yảlâ al-Maushâli, diedit oleh Husain Sâlim Asad, Beirut: Dâr al-Mảmûn li Turâts, 1410 H/1990 M.

Thalbah, Hisham (et.al), Ensiklopedia Mukjizat Al-Qur'an dan Hadis, diterjemahkan oleh Syarif Hade Masyah (et.al), t.tp: Sapta Sentosa, 2009.

Thûsî, Muhammad bin al-Hasan, at-Tibyân fî̀ Tafsîr Al-Qur'an, Beirut: Dar Ihyầ at-Turâts al-Arabiyyah, t.th.

Zakariya, Abi Husain Ahmad bin Fâris, Mu’jam Maqâyis al-Lughah, diedit oleh Abd al-Salâm Muhammad Hârun, Libanon: Dar al-Islâmiyyah, 1410 H/1990 M.

Zamakhsyari, Abî al-Qâsim Mahmûd bin 'Umar, al-Kasysyâf 'an Haqâiq Ghawâmidh atTanzîl wa 'Uyûn al-Aqâwîl fî̀ Wujûh at-Ta'wîl, diedit oleh Ahmad Abd al-Maujûd dan 'Alî Muhammad Muawwad, Riyad: Maktabah Abikan, 1418 H/1998 M. 
IDENTITAS ÂZAR DALAM LITERATUR TAFSIR NUSANTARA

18 | Al-Fanar: Jurnal Ilmu Al-Qur'an dan Tafsir 